\title{
Optimization of Aeration and Agitation for $\alpha$-amylase production by Aspergillus flavus from water hyacinth
}

\author{
Enas M. Mostafa ${ }^{1}$, Mostafa M. Abo Elsoud ${ }^{2, *}$, Marwa S. Salem ${ }^{3}$, Eman I. \\ El-Tabakh ${ }^{3}$, Nagwa M. Sidkey ${ }^{3}$ \\ ${ }^{1}$ Chemical Engineering and Pilot Plant Department, National Research Centre, Egypt \\ ${ }^{2}$ Microbial Biotechnology Department, National Research Centre, Egypt \\ ${ }^{3}$ Department of Botany and Microbiology, Faculty of Science, Al Azhar University (Girls Branch), Cairo, Egypt \\ * Corresponding author: masnrc@gmail.com
}

\begin{abstract}
Amylases are a group of commercially important enzymes with various clinical, medical and biotechnological applications. The current study aims to optimize the agitation and aeration (oxygen transfer) conditions for $\alpha$-amylase production by Aspergillus flavus using water hyacinth extract; as an available waste and very cheap nutritional substance, in a lab scale stirred tank bioreactor (submerged fermentation). Data showed that the maximal cell biomass and enzyme specific activity were reached at low aeration rate $(0.5 \mathrm{v} / \mathrm{v} / \mathrm{m})$ and moderate agitation speed $(200 \mathrm{rpm})$. The maximum specific amylase production rate has been reached after 24 hrs. In addition, it has been confirmed that scaling-up Aspergillus flavus does not, inversely, affect $\alpha$-amylase productivity compared with flask level production. Aspergillus flavus has been approved as promising fungal isolate for production of a-amylase using water hyacinth for application in many fields.
\end{abstract}

Keywords: $\alpha$-amylase; Fermentation; Bioreactor; Aeration; Agitation; Water hyacinth.

\section{1- Introduction}

Amylases are class of enzymes that catalyze the hydrolysis of starch and similar polysaccharides to produce smaller oligosaccharides, maltose and/or glucose units [1]. $\alpha$ amylases, $\beta$-amylases and glucoamylases are among the various amylases that rank first in terms of their commercial and industrial exploitation. Amylases represent, approximately, about $25-33 \%$ of the world enzyme market [2, 3 and 4$]$ and expected to increase during the years.

Alpha-amylase (E.C. 3.2.1.1.) is an extra-cellular, starch-degrading enzyme which catalyzes break-down of the endo $\alpha-1,4-\mathrm{O}$-glycosidic bonds in starch to lower molecular weight products, such as maltotriose, maltose and glucose units with the retention of $\alpha$-anomeric configuration [5]. Although acting on intra-bonds, $\alpha$-amylases are nonspecific and, randomly, act during hydrolysis. It has many applications all starch-based industries such as detergent, textiles and paper industries, food and pharmaceutical industries, animal feed, baking, alcohol fermentation, [6 and 7]. Bacteria, fungi, yeasts, and actinomycetes are the main sources for industrial production of $\alpha$-amylases under submerged mode of fermentation [8, 9 and 10]. Generally, the bacterial and fungal sources of enzymes are more favorable for industrial applications [11]. 
For scaling-up of microbial $\alpha$-amylase production from flask to industrial levels, the optimization of culture conditions in fermentation processes is mandatory [12]. So far, it has been reported that the stirred-tank reactors (STRs) is the most common laboratory scale fermenters used for studying Submerged Fermentation (SmF) [13]. The production of microbial amylases in the fermentation process depends on several factors; chemical composition of the production medium, type of strain, and also fermentation conditions i.e. agitation, dissolved oxygen concentration, temperature, $\mathrm{pH}$, etc. [14].

In stirred tank bioreactors agitation and aeration are two main important operational parameters in the scaling up of the aerobic biosynthesis systems and industrial bioprocess development [15]. In aerobic fermentation, the presence of oxygen influences the enzyme secretion which may be attributed to the metabolic activities in the organism [16]. It has been reported by many researchers that amylase production by Bacillus spp. is highly affected by the presence of dissolved oxygen. Consequently, providing air to the fermentation medium using compressor under sterile conditions could be a promising process as it offers higher efficiency by combining agitation with aeration [17].

Water hyacinth (Eichhornia crassipes solms) is an aquatic, free-floating and flowering invasive plant. It was recorded in the Nile river of Egypt at the end of the $19^{\text {th }}$ century. It has been reported by Batanouny and El-Fiky [18] that during the growing season and after 200 days, a plant of water hyacinth would produce about 3,418,800 new offsets, which cover 14, $928 \mathrm{~m}^{2}$ of the river surface area. It has many negative impacts all over the world as it disrupts the waterbody and aquatic environment. It clogs the waterways including irrigation canals, ruins fishing grounds, destroys paddy rice fields etc. On the other hand, it has been reported to contain $26.9 \%$ total carbohydrates, $49.6 \%$ protein and $16 \%$ total lipids [19] which can represent a fermentable waste substrate for microbial biosynthesis of add-value products [20 and 21].

The present study intends to optimize and investigate the effect of incubation time, agitation speed and aeration rate on the production of $\alpha$-amylase by Aspergillus flavus under Lab-scale bioreactor using water extract of Water hyacinth.

\section{2- Materials and Methods}

This work is part and completion of a project for optimization and production of microbial $\alpha$-amylase starting from shake-flask up-to bench scale using $2 \mathrm{~L}$ bioreactor.

\section{Organism:}

The fungus Aspergillus flavus was isolated, purified and identified using 18S rRNA as it has been reported in the previous work (under publication). This fungus was recorded in the Genbank under the Accesion number (MN559650.1).

\section{Medium preparation:}

The medium composition used in the current work is the flask level results of optimization process reported in the previous work [22]. The medium was prepared as follows:

Water hyacinth $(8.5 \mathrm{~g})$ was cut in to small pieces and then added to tap water $(100 \mathrm{ml})$, autoclaved for 5 minutes and filtered through a piece of cotton. To the obtained filtrate, 3.65 
$\%$ Starch, $0.114 \% \mathrm{NaNO}_{3}$ and 109 ppm Vitamin $\mathrm{B} 6$ were added. The medium was adjusted at $\mathrm{pH} 4.4$, autoclaved and allowed to cool before inoculation. The culture was incubated at $36^{\circ} \mathrm{C}$ for 4 days.

\section{Bioreactor and Conditions:}

The production of $\alpha$-amylase enzyme was studied under different aeration rates viz. $0,0.5$ and $1 \mathrm{v} / \mathrm{v} / \mathrm{m}$ and at different agitation speeds viz. 150, 200 and $250 \mathrm{rpm}$ in 2 liter bioreactor (CelliGen Plus, New Brunswick, United States). The apparatus was supplemented with temperature control system, spurger for gas addition, agitator with two marine impellers and pH sensors. A sample was collected daily and assayed for $\alpha$-amylase specific activity (enzyme activity and total proteins), $\mathrm{pH}$, dissolved oxygen and cell mass dry weight.

Specific growth rate and specific amylase production rate were calculated by the differentiation of the polynomial equation fitted for the experimental data of biomass dry weight and specific activity of amylase produced per unit biomass dry weight.

The analysis, calculations and graphical representation of data were performed in Microsoft Excel 2019.

\section{Assay for $\alpha$-amylase activity:}

The enzyme assay is based on hydrolysis of starch and then determination of the total reducing sugar produced as a result of enzyme activity using dinitrosalysilic [23].

$\boldsymbol{\alpha}$-amylase unit $(\mathbf{U})$ was defined as the amount of the enzyme required to catalyze the liberation of reducing sugar equivalent to $1 \mathrm{mg}$ of glucose per minute under the assay conditions.

\section{Protein determination:}

Protein content of the samples was determined using Folin reagent by the method reported by Lowery et al. [24]. Bovin serum albumin was used for preparation of the standard protein curve.

\section{Biomass dry weight:}

The cell biomass was collected from samples by filtration using Whatman filter paper No. 1 and then oven dried to constant weight. The eight of the biomass was determined in $(\mathrm{g} / \mathrm{l})$.

\section{3- Results}

The data obtained from all the fermentation processes were analysed and calculated on Microsoft Excel 2019. The data were represented in charts and the trend lines along with correlation coefficients $\left(\mathrm{R}^{2}\right)$ were plotted on each chart. All the calculated $\mathrm{R}^{2}$ showed excellent correlations between data.

\section{Comparison between three levels of aeration for the production of $\alpha$-amylase:}

Data in figures (1-5) show that the specific growth of the fungus Aspergillus flavus and $\alpha-$ amylase production rates were higher at $0.5 \mathrm{v} / \mathrm{v} / \mathrm{m}$ aeration rate. The dry cell mass reached about $10 \mathrm{~g} / \mathrm{l}$ at $0.5 \mathrm{v} / \mathrm{v} / \mathrm{m}$ after 24 hours which was the maximum production level. The maximum specific activity was reached at $0.5 \mathrm{v} / \mathrm{v} / \mathrm{m}$ at the end of incubation time. The $\mathrm{pH}$ at $0.5 \mathrm{v} / \mathrm{v} / \mathrm{m}$ show minimum variation from that at zero time though the whole run compared with $0.0 \mathrm{v} / \mathrm{v} / \mathrm{m}$ and $1 \mathrm{v} / \mathrm{v} / \mathrm{m}$. The rates for specific growth and production at $0.5 \mathrm{v} / \mathrm{v} / \mathrm{m}$ and $1 \mathrm{v} / \mathrm{v} / \mathrm{m}$ 
showed very close results compared with that at $0.0 \mathrm{v} / \mathrm{v} / \mathrm{m}$.

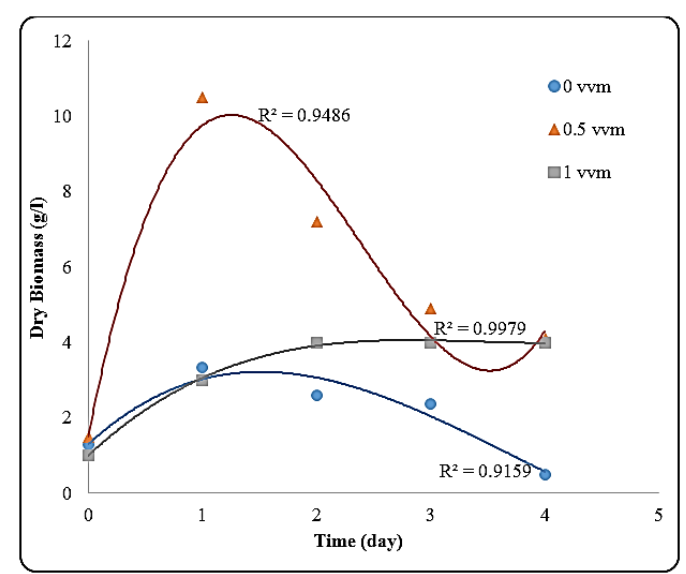

Fig. 1 Comparison between biomass dry weights produced using three aeration levels for the production

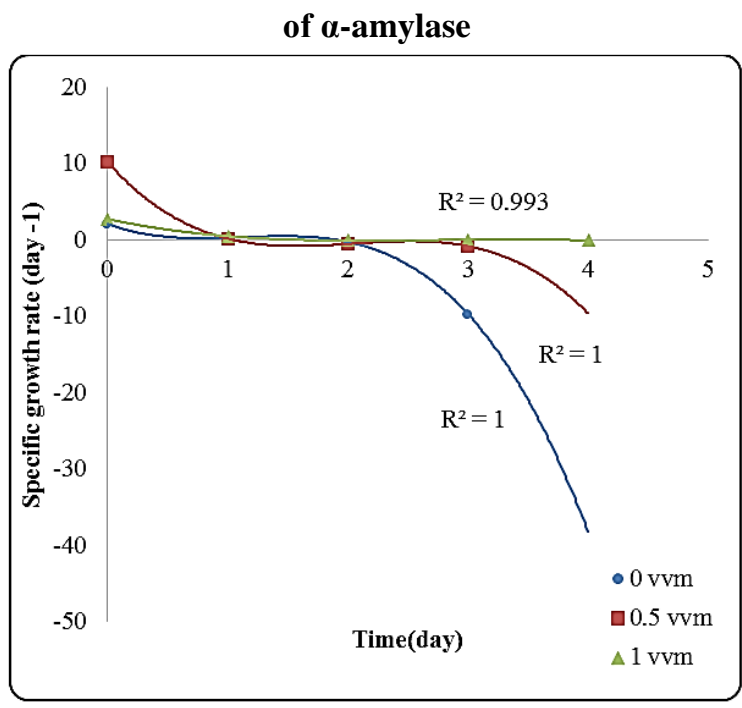

Fig. 2 Comparison between specific growth rates of amylase produced using three aeration levels for the production of $\alpha$-amylase

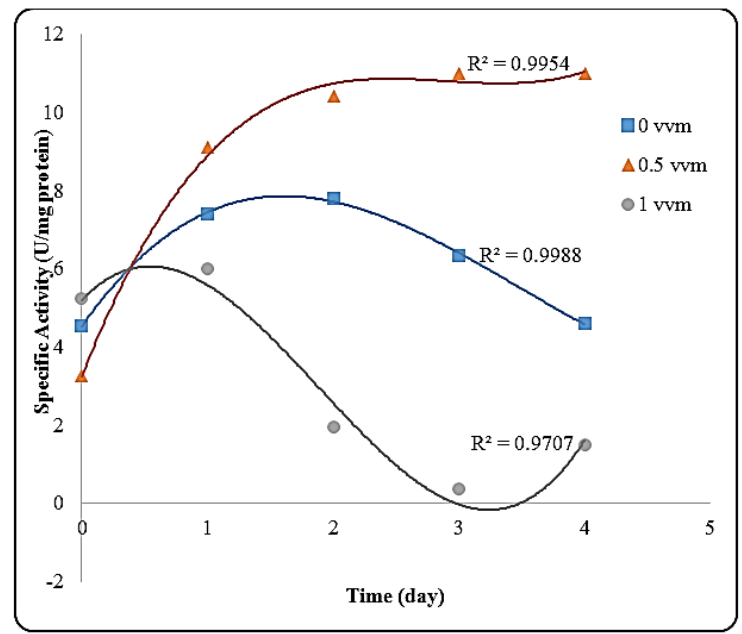

Fig. 3 Comparison between specific activities of amylase produced using three aeration levels for the production of $\alpha$-amylase 


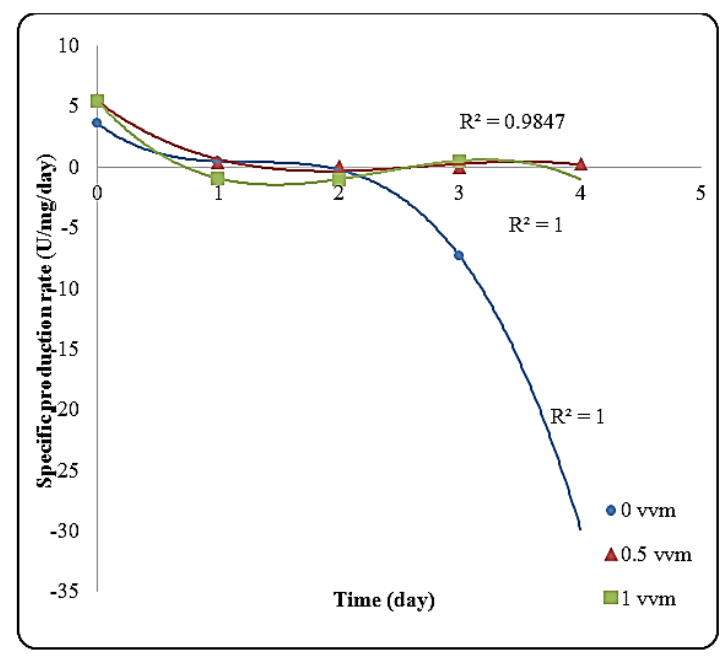

Fig. 4 Comparison between specific production rates of amylase produced using three aeration levels for the production of $\alpha$-amylase

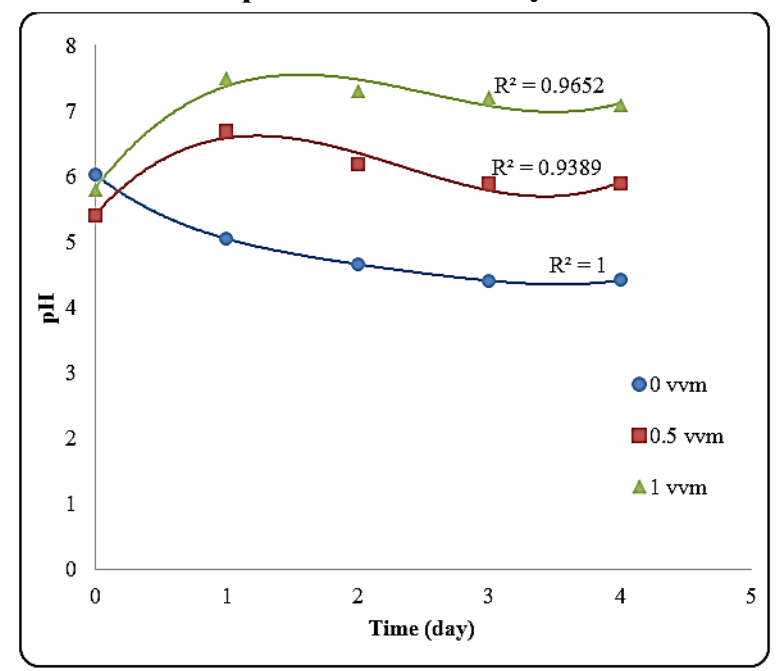

Fig. 5 Comparison between pH recorded for amylase produced using three aeration levels for the production of $\alpha$-amylase

\section{Comparison between three levels of agitation for the production of amylase}

Through figures (6-10), data show that the growth, specific growth and $\alpha$-amylase production rates of the fungus Aspergillus flavus were higher at $200 \mathrm{rpm}$ agitation speed compared with $150 \mathrm{rpm}$ and $250 \mathrm{rpm}$. The specific activity of amylase was maximum (>10 $\mathrm{U} / \mathrm{mg}$ protein) at agitation speed $200 \mathrm{rpm}$ at the end of the incubation period. 


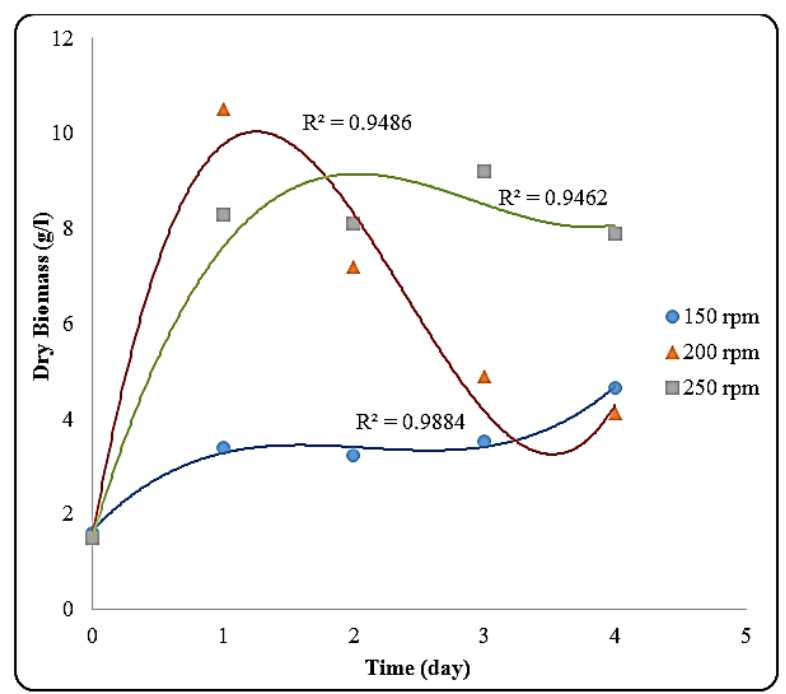

Fig. 6 Comparison between biomass dry weights produced using three agitation levels for the production of $\alpha$-amylase

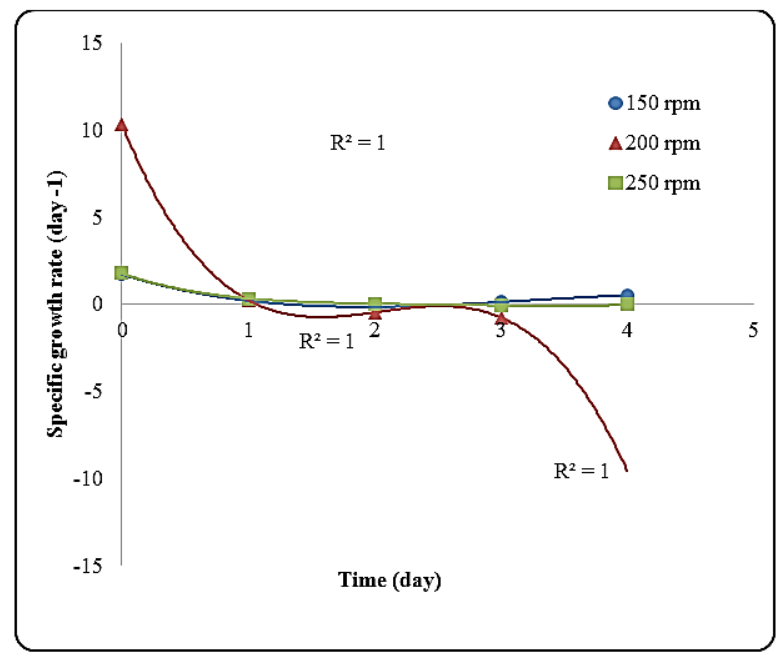

Fig. 7 Comparison between specific growth rates of amylase produced using three agitation levels for the production of $\alpha$-amylase

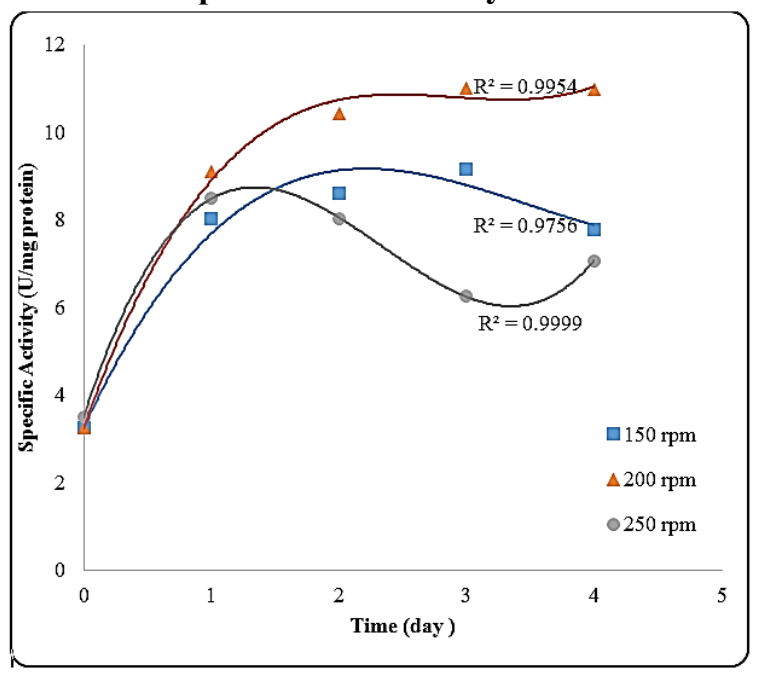

Fig. 8 Comparison between specific activities of amylase produced using three agitation levels for the production of $\alpha$-amylase 


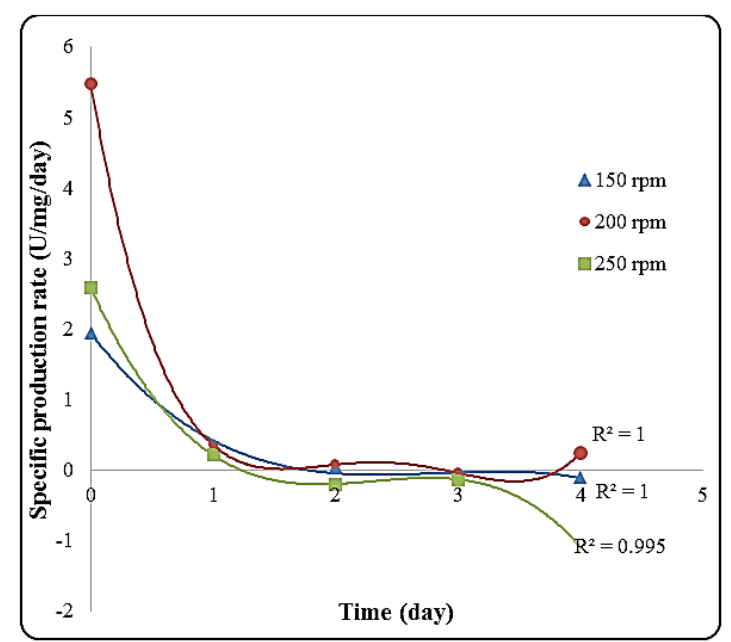

Fig. 9 Comparison between specific production rates of amylase produced using three agitation levels for the production of $\alpha$-amylase

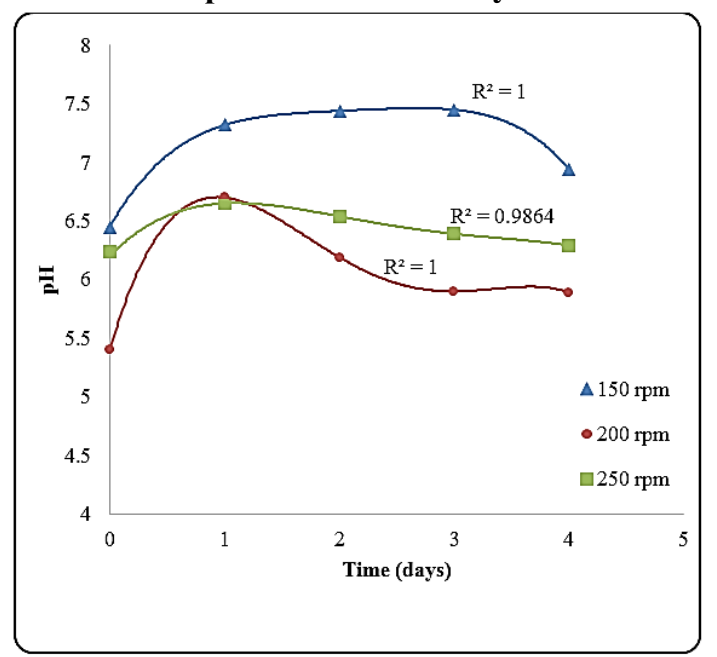

Fig. 10 Comparison between pH recorded of amylase produced using three agitation levels for the production of $\alpha$-amylase

\section{4- Discussion}

It is well known that the industrial production of microbial extracellular enzymes in bioreactors is affected by the chemical composition of production medium and various physical and environmental factors [25]. The scaling-up of the fermentation processes from lab to commercial levels is facing a challenging problem which is the difficulty to track the impact of factors influencing the scaling-up during the fermentation bio-process [26]. One of the major problems facing scaling-up microbial production is the simulation of shaking process in the flask level. However, agitation and aeration (oxygen transfer) can be used to perform the functions of shaking process including homogenization of the production medium and dissolution of oxygen. Therefore, studying the effect of aeration rate and agitation speed on enzyme production on a lab scale levels might provide more comprehensive understanding and reliability about the enzyme synthesis conditions.

Recently, it has been reported in some studies a phenomenon called "impeller flooding" in which at lower agitation speeds accompanied by higher aeration flows, the air stream up in the bioreactor increased along the stirrer shaft resulting in poor mixing, reduced air dispersion and 
diminished oxygen transfer rates. This phenomenon results in a column of air surrounds the impeller, consequently, there will no longer be a proper contact between air and liquid in the vessel. This phenomenon has to be avoided during the production bio-process by finding an appropriate combination of agitation speed and aeration rate together [27]. This study supports this phenomenon as it indicated that a low aeration rate of $0.5 \mathrm{v} / \mathrm{v} / \mathrm{m}$ with moderate agitation speed of $200 \mathrm{rpm}$ resulted the highest; biomass concentration and specific enzyme activity after only $24 \mathrm{hrs}$ fermentation time. Reducing the fermentation time in parallel with increasing productivity is a major economic factor in industrial scale production.

In the presence of low concentrations of the dissolved oxygen, the metabolic process of Aspergillus flavus diminishes to minimum levels as oxygen is one of the essential requirements for microbial growth and activity [28]. On the other hand, the increase in levels of dissolved oxygen (hyperoxia) may be toxic as it may produce excess levels of reactive oxygen species (ROS) that accumulate in the microbial cells causing cell death [29]. Furthermore, ROS could contribute in chemical changes in the produced enzyme(s) by protein carbonylization which reduces its activity [30]. This case was encountered in this study as the biomass and enzyme production were very low at $0 \mathrm{v} / \mathrm{v} / \mathrm{m}$ and $1 \mathrm{v} / \mathrm{v} / \mathrm{m}$ aeration rate while $0.5 \mathrm{v} / \mathrm{v} / \mathrm{m}$ aeration rate supplied the required oxygen for the process instead of the oxygen starvation at $0 \mathrm{v} / \mathrm{v} / \mathrm{m}$ and the over flooding of oxygen at $1 \mathrm{v} / \mathrm{v} / \mathrm{m}$ which affected the specific biomass growth rate and the specific amylase production rate to be at their highest values through the first $24 \mathrm{hrs}$.

Agitation has a crucial role in the improvement of the interfacial gas/ liquid exchange through increasing the available gas area by breaking the air stream into smaller bubbles [31]. The increase in agitation rate causes destruction of the microbial cells through imposing high sheer stress [32] and, also, production of higher ROS. On the other hand, at lower agitation speeds, improper mixing of nutrients and oxygen may, ultimately, affect amylase yield [32]. It has been reported that the agitation speed affects the morphology and, subsequently, the microbial biosynthetic activity [33]. This study was in agreement with previous published work.

In this study it's obvious that $\alpha$-amylase production from Aspergillus flavus was maximal at $0.5 \mathrm{v} / \mathrm{v} / \mathrm{m}$ aeration rate and $200 \mathrm{rpm}$ agitation speed. Noteworthy, at these conditions, the specific amylase activity reached about 10 (U/mg protein) after 48 hours of the fermentation process while biomass dry weight reached its maximal value about $10 \mathrm{~g} / \mathrm{l}$ after only 24 hours at which the specific enzyme activity was about 9 (U/mg protein). This incubation period is 72 hours less than that in shake flask. This note may not only reduce the production time but the production cost, also. The lag phase was significantly shortened in the bioreactor compared with shake flask. In stirred tank bioreactor, the lag phase was much faster and after only about $16 \mathrm{~h}$ of incubation, the fungal growth entered the logarithmic phase to reach the maximum production after 24 hours. The longer fermentation process in shake flask cultures may be attributed to the limited gas exchange and oxygen uptake. In shake flasks, most cultures, rapidly, reach death phase when the available ambient oxygen is depleted from the surrounding medium [34]. 
At the optimum aeration rate $(0.5 \mathrm{v} / \mathrm{v} / \mathrm{m})$ and agitation speed $(200 \mathrm{rpm})$, few changes in $\mathrm{pH}$ value was noted in the range between 5.5 and 6.5 through all the process period. This result excluded the need to study the effect of constant $\mathrm{pH}$ on the enzyme production and we can conclude that the optimum $\mathrm{pH}$ for $\alpha$-amylase production from the fungus Aspergillus flavus was $6 \pm 0.5$. This $\mathrm{pH}$ value is matched with the results obtained by most researchers [35 and 36] who reported maximum amylase productivity by fungal isolates at the $\mathrm{pH}$ of around 6 . On the other hand, other optimal $\mathrm{pH}$ values were reported by some others [37 and 38].

\section{5- Conclusion}

In a previous study, among the isolated fungi from fermented water hyacinth, A. flavus has been found as an appropriate isolate for production of $a$-amylase. In addition, screening and optimization of the significant factors affecting $a$-amylase production were conducted in the flask level with the purpose of lowering the production cost of fermentation medium containing water hyacinth extract. In the current work, we have attempted to optimize the aeration and agitation conditions for $\alpha$-amylase production from $A$. flavus in a lab scale stirred tank bioreactor. The results showed that the maximal $a$-amylase productivity was obtained at 0.5 $\mathrm{v} / \mathrm{v} / \mathrm{m}$ aeration rate and $200 \mathrm{rpm}$ agitation speed at $36^{\circ} \mathrm{C}$ after only a single day of incubation. This incubation time is shorter compared to the flask experiments and subsequently may reduce the production cost. Kinetic study of the fermentation parameters confirms the prevalence of fermenter cultures. Further studies should be performed in pilot-scale for scaling up before commercialization and testing larger samples in production scale. Furthermore, the success of the enzyme production testing in fed batch fermentation system is going to be a bonus for economic commercial production.

\section{References}

[1] A. Sundarram, and T.P.K. Murthy, " $\alpha$-amylase production and applications: A review". J. Applied Environ. Microbiol., Vol. 2, pp. 166-175, 2014.

[2] M. Mobini-Dehkordi, and Fa Javan, "Application Of Alpha amylase In Biotechnology". J Biol Today's World Vol. 1, pp. 15-20, 2012. Https://Doi.Org/10.15412/J.Jbtw.01010104.

[3] Apa De Oliveira, M. Silvestre, H. Alves-Prado, A. Rodrigues, M. Da Paz, G. Fonseca, and R. Leite, "Bioprospecting of yeasts for amylase production in solid state fermentation and evaluation of the catalytic properties of enzymatic extracts". Afr J Biotechnol Vol. 14, pp. 1215-1223, 2015. https://doi.org/10.5897/AJB2014.14062

[4] S. Tiwari, R. Srivastava, C. Singh, K. Shukla, R. Singh, P. Singh, R. Singh, N. Singh and R. Sharma, "Amylases: An overview with special reference to alpha amylase". J Global Biosci., Vol. 4, pp. 18861901, 2015.

[5] P. Tomasik, D. Horton, "Enzymatic conversions of starch". Advances in Carbohydrate Chemistry and Biochemistry, Vol. 68, pp. 59-436, 2012.

[6] H. Admassu, W. Zhao, R. Yang, Ma Gasmalla and W. Zhang "Recent advances on efficient methods for a-amylase production by solid state fermentation (SSF)". Int J Adv Res., Vol. 3, pp. 1485-1493, 2015.

[7] D. Balakrishnan, S. S. Kumar, and S. Sugathan, "Amylases for Food Applications-Updated Information". In Parameswaran B., Varjani S., Raveendran S., Green Bio-processes: Enzymes in Industrial Food Processing. Springer Nature Singapore, 2019, Pte Ltd., Singapore. ISBN 978-981-13-3263-0. https://doi.org/10.1007/978-981-13-3263-0.

[8] N. M. Sidkey, M.A. Abo-Shadi, A.M. Al-Mutrafy, F. Sefergy, N. Al-Reheily, "Screening of Microorganisms Isolated from some Enviro-Agro-Industrial Wastes in Saudi Arabia for Amylase Production". Journal of American Science, Vol. 6(10), pp. 926-939, 2010. https://www.researchgate.net/publication/317169982 
[9] N. M. Sidkey, M.A. Abo-Shadi, R. Balahmar, R. Sabry and G. Badrany, "Purification and characterization of $\alpha$-amylase from a newly isolated Aspergillus flavus F2Mbb". International Research Journal of Microbiology, Vol. 2(3), pp. 96-103, 2011.

[10] M. Naidu, "Bacterial Amylase: A Review". Int J Pharm Biol Arch., Vol. 4, pp. 274-287, 2013.

[11] Pm De Souza, "Application of microbial a-amylase in industry- A review". Braz J Microbiol., Vol. 41, pp. 850-861, 2010. https://doi.org/10.1590/S1517-83822010000400004

[12] A. Deljou, I. Arezi, and M. Khanahmadi, "Scale-up thermostable $\alpha$-amylase production in lab-scale fermenter using rice husk as an elicitor by Bacillus licheniformis-AZ2 isolated from Qinarje Hot Spring (Ardebil Prov. of Iran)". Periodicum Biologorum, Vol. 120(1), pp. 11-21, 2018.

[13] Cr. Soccol, A. Pandey, and C. Larroche, "Fermentation Processes Engineering in the Food Industry". CRC Press, Tylor \& Francis Group, Florida, p 510, 2013.

[14] S. Abbasiliasi, J.S. Tan, F. Bashekouh, T.A.T. Ibrahim, S. Mustafa, F. Vakhshiteh, and A. B. Ariff, "In vitro assessment of Pediococcus acidilactici Kp10 for its potential use in the food industry". BMC Microbiol., Vol. 17, pp. 121-132, 2017. doi: 10.1186/s12866-017-1000-z.

[15] C. Bandaiphet, and P. Prasertsan, "Effect of aeration and agitation rates and scale-up on oxygen transfer coefficient, KLa in exopolysaccharide production from Enterobacter cloacae WD7". Carbohydrate Polymers, Vol. 66(2), 216-228, 2006.

[16] T. Zotta, E. Parente, and A. Ricciardi, "Aerobic metabolism in the genus Lactobacillus: impact on stress response and potential applications in the food industry". Journal of Applied Microbiology, Vol. 122(4), 2017.

[17] E. A. Elmansy, M. Asker, E. M. El-Kady, S. M. Hassanein and F. M. El-Beih, "Production and optimization of $\alpha$-amylase from thermo-halophilic bacteria isolated from different local marine environments". Bulletin of the National Research Centre, Vol. 42(1), 2018.

[18] K.H. Batanouny, and A.M. El-Fiky, "The water hyacinth (Eichhornia crassipes solms) in the Nile system, Egypt". Aquatic Botany, Vol. 1, pp. 243-252, 1975.

[19] I. Hang, T. Rinttila, J. Zentek, A. Kettunen, S. Alaja, J. Apajalahti, J. Harmoinen, W. M. de Vos and T. Spillmann, "Effect of high contents of dietary animal-derived protein or carbohydrates on canine faecal microbiota". BMC Vet. Res.,Vol. 8, pp. 90, 2012.

[20] N.M. Sidkey, S. M. Shash and M. S. Ammar, "Regulation of alpha-amylase(s) Biosynthesis by Aspergillus sp. S-7 Attacking the Nile Hyacinth Homogenates Produced Under Laboratory Scale Fermentation Conditions". Al-Azhar Bull. Sci., Vol. 7(1), pp. 473-488, 1996.

[21] N.M. Sidkey, S. M. Shash and M. S. Ammar, "Biodegradation of Water Hyacinth Through Certain Hydrolytic Enzymes Secreted by Different Fungal Isolates Representing The Fungal Microflora of Water Hyacinth". Al-Azhar Bull. Sci., Vol. 8(2), pp. 579-594, 1997.

[22] E. I. El-Tabakh, M. M. Abo Elsoud, M. S. Salem and N. M. Sidkey, "Production of $\alpha$-amylase(s) by Aspergillus flavus, F7 attacking water hyacinth ground preparation (WHGP) under solid state fermentation". Journal of Inventions in Biomedical and Pharmaceutical Sciences (JIBPS), Vol. 5 (3), pp. 5-14, 2020.

[23] G.L. Miller, "Use of dinitrosalicylic acid reagent for determination of reducing sugar". Analytical Chemistry, Vol. 31, pp. 426-428, 1959. doi:10.1021/ac60147a030.

[24] O.N. Lowery, A.F. Rosebrough, and R. Randall, "Protein measurement with folin phenol reagent". J. Biol. Chem, Vol. 193, pp. 265-275, 1951.

[25] N. Y. Farkye, "CHEESE | Microbiology of Cheesemaking and Maturation. In C. A. B.L. Tortorello (Ed.)", Encyclopedia of food microbiology (2nd ed., pp. 395-401), 2014. Oxford: Academic Press.

[26] J. S. Crater and J. C. Lievense, "Scale-up of industrial microbial processes". FEMS Microbiol Lett., Vol. 365(13): fny138, 2018. doi: 10.1093/femsle/fny138. PMID: 29860483; PMCID: PMC5995164.

[27] A. Karimi, F. Golbabaei, M. Mehrnia, M. Neghab, K. Mohammad, A. Nikpey, and M. Pourmand, "Oxygen Mass Transfer in a Stirred Tank Bioreactor Using Different impeller Configurations for Environmental Purposes". Iranian journal of environmental health science \& engineering, Vol. 10, 2013. 6. 10.1186/1735-2746-10-6.

[28] J.M. Chern, S.R. Chou, and C.S. Shang, "Effects of impurities on oxygen transfer rates in diffused aeration systems". Wat. Res., Vol. 35(13), pp. 3041 - 3048, 2000.

[29] A. Baez, and J. Shiloach, "Effect of elevated oxygen concentration on bacteria, yeasts, and cells propagated for production of biological compounds". Microbial Cell Factories, Vol. 13(181), 2014.

[30] K. Ciacka, U. Krasuska, P. Staszek, A. Wal, J. Zak and A. Gniazdowska, "Effect of Nitrogen Reactive Compounds on Aging in Seed". Front. Plant Sci., Vol. 11, pp. 1011, 2020. doi: 10.3389/fpls.2020.01011

[31] A. Mandal, "Gas-Liquid Two-Phase Flow in an Ejector Induced Downflow Bubble Column". LAP LAMBERT Academic Publishing, India, 2010. 
[32] S. M. Nadeem, Z. A. Zahir, M. Naveed, and M. Arshad, "Rhizobacteria containing ACC-deaminase confer salt tolerance in maize grown on salt-affected fields". J. Microbiol. Vol. 55, pp. 1302-1309, 2009. doi: 10.1139/w09-092

[33] D. Ibrahim, H. Weloosamy, and S. Lim, "Effect of agitation speed on the morphology of Aspergillus niger HFD5A-1 hyphae and its pectinase production in submerged fermentation". World Journal of Biological Chemistry, Vol. 6(3), pp. 265-71, 2015.

[34] Km. Obom, A. Magno, and Pj. Cummings, "Operation of a benchtop bioreactor". J. Vis. Exp. Vol. 79, pp. 50582, 2013. https://doi.org/10.3791/50582

[35] T. N. Nwagu and B. N. Okolo, "Extracellular amylase production of a thermotolerant Fusarium sp. isolated from Eastern Nigerian soil". Braz. arch. biol. technol., Vol. 54(4), 2011.

[36] S. Mikai, I. Nanako, J. Konomi, Y. Sato, M. Era, J. Ninomiya, and H. Morita, "Simultaneous Increase of Glucoamylase and $\alpha$-Amylase Production in Submerged Co-culture of Aspergillus and Rhizopus Strains". Japan Journal of Food Engineering, Vol. 16(2), pp. 111 - 121, 2015.

[37] B. Zaferanloo, S. Bhattacharjee, M. M. Ghorbani, P. J. Mahon, and E. A. Palombo, "Amylase production by Preussia minima, a fungus of endophytic origin: optimization of fermentation conditions and analysis of fungal secretome by LC-MS. BMC Microbiol., Vol. 14: 55, 2014.

[38] M. A. Uygut and M. S. Tanyildizi "Determination of Effective Parameters for Alpha-Amylase Production in a Modified Rotating Drum Bioreactor. Arabian Journal for Science and Engineering, Vol. 43, pp. 3381-3391, 2018. 